\title{
Golden apple snail (Pomacea canaliculata) as an alternative protein source in Pasupati catfish (Pangasius sp.) fish feed
}

\author{
MEILISHA PUTRI PERTIWI", DINA DYAH SAPUTRI \\ Department of Biology Education, Faculty of Education and Teacher Training, Universitas Pakuan. Jl. Pakuan PO Box 452, Bogor 16143, West Java, \\ Indonesia. Tel: +62-251-8312206, Fax: 62-251-8356927, •email: meilisha.putri@unpak.ac.id
}

Manuscript received: 12 October 2020. Revision accepted: 6 November 2020.

\begin{abstract}
Pertiwi MP, Saputri DD. 2020. Golden apple snail (Pomacea canaliculata) as an alternative protein source in Pasupati catfish (Pangasius sp.) fish feed. Nusantara Bioscience 12: 162-167. Research on efforts to conserve golden apple snail (Pomacea canaliculata) meat has been done. This research aimed to utilize the snail meat as an alternative feed for the Pasupati catfish (Pangasius sp.). The research was carried out from May to August 2020. It began by collecting Pomacea canaliculata by hand sorting then processed into artificial feed/pellets. The research was CRD designed with 5 treatments and 3 replications. Pasupati catfish juvenil measuring $7.4 \pm 0.8$ $\mathrm{cm}$ and weighing $11.7 \pm 0.5 \mathrm{~g}$, was maintained for 21 days with a stocking density of 15 individuals/aquarium. Feeding as much as $8 \%$ of the biomass with a frequency of feeding 3 times a day at satiation. Variables measured were SGR, L, RP, FCR, and SR. The results showed that feed B produced the best fish growth and could be an alternative fish feed without having a negative effect on growth and feed utilization. Feed B (90\% fish meal $+10 \%$ Pomacea canaliculata meat meal) had the highest SGR value and was supported by a high PR value and a low FCR value. In addition, there is a difference among variables, despite least significant. ANOVA test also supports the differences between treatments, but HSD test $(\mathrm{p}<0,05)$ is not significantly different. This means that the addition of the percentage of $P$. canaliculata meat meal to the feed does not provide a good performance of the Pasupati catfish. Value of abiotic parameters was to support fish farming.
\end{abstract}

Keywords: Alternative feed, conservation, Pasupati catfish, Pomacea canaliculata

\section{INTRODUCTION}

The golden apple snail (GAS) or Pomacea canaliculata is one of the four introduced species of Pomacea ( $P$. insularum, $P$. scalaris, $P$. diffusa) which is widely distributed in 15 of 22 countries in the southern region of Asia. When this species native to South America was introduced to Taiwan from Argentina, certain objectives were to be achieved (Hayes et al. 2008). Further explained by Naylor (1996), it was hoped that $P$. canaliculata can be a source of high protein for local consumption. Besides, it was also an export commodity, especially to industrialized countries that were popular with the escargot menu. As a result of this process, $P$. canaliculata has grown out of control and becomes a pest of rice fields. This results in high economic losses (Naylor 1996; Cowie 2002). Even $P$. canaliculata are included in the list of 100 pests difficult to control (Joshi 2007).

One of the most effective efforts to control snail pests is to process them into useful products. The processing of $P$. canaliculata has been used for nutritious chemicals and food products. $P$. canaliculata have been used as natural attractant traps (Sari 2019) and Liquid Organic Fertilizer/LOF (Siregar and Lubis 2017). P. canaliculata have also been studied as raw material for chips (Alfathir and Estiasih 2018) as well as nutritional additives in complementary foods (Marsyha et al. 2017). In addition, $P$. canaliculata are also used as an alternative for duck feed (Subhan and Yuwanta 2015), snakehead murrel fish feed for $P$. canaliculata percentage in order $12.5 \%$; $25 \%$; $37.5 \%$; $50 \%$ snakehead murrel fish feed for $P$. canaliculata percentage in order $12.5 \% ; 25 \% ; 37.5 \%$; $50 \%$ (Hidayat et al. 2013), and vannamei shrimp feed (Agustono et al. 2016; Anggraini et al. 2018), and vannamei shrimp feed for $P$. canaliculata percentage in order $10 \% ; 20 \% ; 30 \%$.

The use of $P$. canaliculata has the potential as an alternative feed. The proximate analysis that has been carried out (Saputri and Pertiwi 2019, unpublished data) on the $P$. canaliculata meat gives a result of $40 \%$. This value has the potential considering the need for fish protein is around 28-30\% (Savitri et al. 2015). The cost requirement for fish feed procurement is relatively large, namely 70$90 \%$ of the total production (Hung et al. 2007; Phuong et al. 2007; Da et al. 2011). Therefore, the protein content in the $P$. canaliculata meat has the potential as an alternative to fish feed.

Pasupati catfish is the tested fish in this study, because there has been no research with $P$. canaliculata meat to feed the fish. Pasupati catfish is a freshwater fish native to Indonesia from the results of inbreeding between Siamese catfish (Pangasianodon hypophthalmus) and male catfish jambal (Pangasius djambal). Its white flesh, soft texture, and tasty make this fish a high economic value (Gustiano et al. 2012). It was recorded that in 2017-2018, catfish production in Indonesia rose from 245.75 thousand tons to 492 thousand tons $(100.23 \%)$. This data gives the results of the third-ranking of cultivated fish commodities with a percentage of $31.76 \%$ after carp $(68.15 \%)$ and catfish 
(56.32\%) (BPS 2018). This shows that the demand for catfish is increasing from year to year.

The high demand for commercial fish feed and an effort to substitute fish feed are needed to encourage this research. The main objective of this research is to conserve snails into a useful product. The product being developed is in the form of $P$. canaliculata meat flour as an alternative to Pasupati catfish feed. This study aims to see the effect of substitution of fish meal with $P$. canaliculata meat meal on the growth of Pasupati catfish.

\section{MATERIALS AND METHODS}

\section{Study area}

The sampling of golden snails was carried out by hand sorting in the paddy fields of Cijeruk Village, Cijeruk Subdistrict, Bogor District, West Java Province, Indonesia (Figure 1).

\section{Procedures}

Pomacea canaliculata sample was separated from the shell and meat by boiling the sample. After perfectly separated, meat sample was dried in the sun for 3-5 days. Then sample was blended until become fine. Furthermore, sample was sorted into 5 plates for each pellet formula. Tapioca was also added for binding pellet. After all things completed, they all were manufactured into pellets A, B, C, $\mathrm{D}$, and E. Before using it, pellet was dried for 3 days in the sun. Then the samples were dried in the sun to dry and used as raw material for making pellets. Its moisture was kept under $70 \%$. The research was conducted by CRD with 5 treatments and 3 replications. As for the feed treatment in the form of a source of feed protein $100 \%$ fish meal (A) as a control, $90 \%$ fish meal $+10 \%$ P. canaliculata meat meal (B), $80 \%$ fish meal $+20 \%$ P. canaliculata meat meal (C), $70 \%$ fish meal $+30 \%$ P. canaliculata meat meal (D), and $60 \%$ fish meal $+40 \% P$. canaliculata meat meal (E). Furthermore, the value of protein level and energy content of each feed is counted after doing proximate analysis.

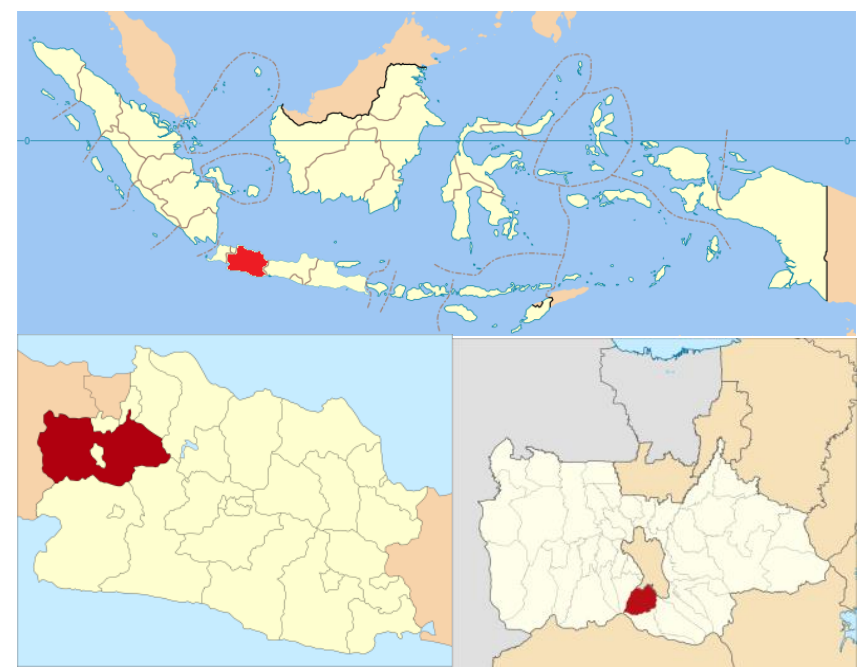

Pasupati catfish (Pangasius sp.) as the fish tested with the weight of the test fish seeds was $7.4 \pm 0.8 \mathrm{~cm}$ and a weight of $11.7 \pm 0.5 \mathrm{~g}$, stocked with a density of 15 fish/tub. The system used is recirculation. The test fish rearing container is 15 units of $57 \mathrm{~cm} \mathrm{x} 36 \mathrm{~cm} \mathrm{x} 29 \mathrm{~cm}$ aquarium, $30 \mathrm{~L}$ water volume equipped with aeration.

Fish were fasted for 1 week before starting treatment. After that, the initial fish were weighed and measured. Fish maintenance is carried out for 21 days by providing feed as much as $8 \%$ of the fish biomass per day (at satiation) and it was around 2-3 grams of pellet. Feeding is done 3 times a day. Sampling is done once a week by measuring as much as $20 \%$ of the number of fish from each replication on the parameters of fish weight and length.

\section{Data analysis}

Proximate analysis was performed on treated feed samples and fish samples at the beginning and at the end of treatment to determine their nutritional content. Meanwhile, the measured abiotic parameters were DO content, temperature, $\mathrm{pH}$, and ammonia levels $\left(\mathrm{NH}_{3}\right)$. The test parameters calculated include SGR, L, PR, FCR, and SR.

The formula for the test parameters is as follows:

$\mathrm{SGR} /$ specific growth rate (\%/day) (Ross and Jauncey 1982):

$$
\mathrm{SGR}=100 \times \frac{\operatorname{In} W t-I n W o}{t}
$$

Where, $\mathrm{Wt}=$ average fish weight at the end of the study (g); Wo = average fish weight at the beginning of the study $(\mathrm{g}) ; \mathrm{t}=$ length of maintenance (days).

Growth of absolute length (Ross and Jauncey 1982):

$$
\mathrm{L}=\mathrm{Lt}-\mathrm{Lo}
$$

Where, $\mathrm{L}=$ growth in length $(\mathrm{cm}) ; \mathrm{Lt}=$ average length of fish at the end of the study $(\mathrm{cm})$; Lo = average length of fish at the beginning of the study $(\mathrm{cm})$.

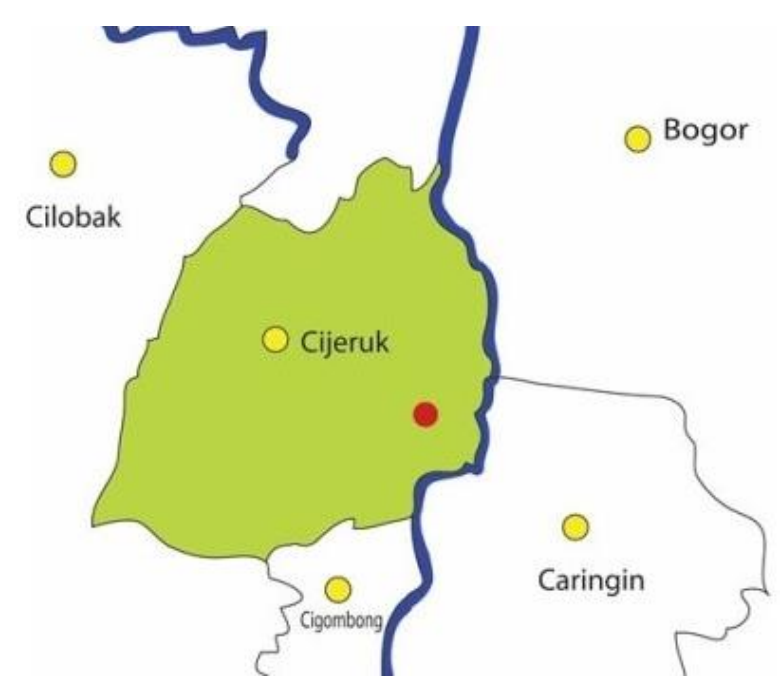

Figure 1. Location of paddy field (@) in Cijeruk Village, Cijeruk Subdistrict, Bogor District, West Java Province, Indonesia 
PR/protein retention (De Silva and Anderson 1995):

$\operatorname{PR}(\%)=\frac{P u}{P c} \times 100 \%$

Where, $\mathrm{Pu}=$ weight of protein stored in fish body $(\mathrm{g} / \mathrm{kg}) ; \mathrm{Pc}=$ weight of protein consumed by fish $(\mathrm{g} / \mathrm{kg})$.

FCR/feed conversion ratio (Ross and Jauncey 1982):

$$
\mathrm{FCR}=\frac{F}{(W t+D)-W o}
$$

Where, $\mathrm{F}=$ amount of feed given during the study $(\mathrm{g})$; $\mathrm{Wt}=$ fish biomass at the end of the study $(\mathrm{g}) ; \mathrm{Wo}=$ fish biomass at the beginning of the study $(\mathrm{g}) ; \mathrm{D}=$ fish biomass that died during the study $(\mathrm{g})$.

SR/survival (De Silva and Anderson 1995):

$$
\mathrm{SR}=\frac{N t}{N o} \times 100 \%
$$

Where, $\mathrm{Nt}=$ number of fish at the end of the study (tail); No = number of fish at the beginning of the study (tail).

The research was experimentally designed and conducted by CRD with 5 treatments and 3 replications. Analysis of SGR, L, RP, FCR, and SR data using SPSS 22 with the ANOVA test then continue with the HSD test or Honestly Significant Difference $(p<0.05)$.

\section{RESULTS AND DISCUSSION}

The experimental fish had an average initial weight of $11.7 \pm 0.5 \mathrm{~g}$. Meanwhile, at the end of the experiment, the average fish weight value was $28.5-33 \mathrm{~g}$ g/biomass. This value indicates a good weight gain for fish. This is in line with Carcamo et al. (2019) stated that the amount of energy in feed affects the weight and length of fish.

The first test parameter measured was the specific growth rate or SGR. The growth rate shows the percentage increase in fish weight every day during the study. Growth is influenced by the balance of nutrients in feed, including protein, fat, carbohydrates, vitamins, and minerals (Seo and Lee 2008; Pulgar et al. 2013). In this treatment, feed protein, fat, and carbohydrate are fulfilled by $P$. canaliculata meat and fish flour. In addition, vitamin was also added and tapioca was used as binder. The need for balanced nutrition in fish feed will vary according to fish age and size, environmental conditions, reproduction, and physiological activity (Ross et al. 2018).

Therefore, the food that is consumed first will be used to nourish the body and replace damaged cells, the rest is used for growth. The SGR parameter can be seen in Figure 3.

The B feed (36.52\% protein energy) had the highest SGR value compared to other feed treatments. Increase in feed protein does not always lead to increased growth. Increasing feed protein without being followed by a balance with non-protein energy sources will cause protein to be used as an energy source (Glencross et al. 2011). It is suspected that there is an excess of protein in the test feeds $\mathrm{C}, \mathrm{D}$, and E, namely the substitution of fish meal with golden snail meat meal of $20 \%$ (31.72\% protein energy), $30 \%$ (38.52\% protein energy) and $40 \%$ (8.78\% protein energy), so that the excess is removed because it is not needed by the body. Meanwhile, the dietary protein requirement of pasupati catfish is $32-40 \%$ (Poernomo et al. 2015; Tahapari and Darmawan 2018). Hu et al. (2008) and Zhang et al. (2017) also state that the excess or lack of protein in feed cannot be used for growth. Added by Sánchez-Lozano et al. (2009) and Heinitz et al. (2018) the higher the protein content, the lower the SGR value. Meanwhile, the parameter L can be seen in Figure 4.

Based on Figure 4, treatment of D feed gave the highest length growth and was only 0.1 different from feed B. As stated earlier that the amount of energy in feed will affect the weight and length of fish (Carcamo et al. 2019). The addition of fish length at the end of the study indicates that fish feed has been effectively used for fish growth.

Protein is an important nutrient for fish (Ganga 2015). Protein needs are different for each type of fish (Kaushik and Seilez 2010; Beveridge et al. 2013). Protein will be optimal for fish growth, if carbohydrate and fat needs are met as an energy source (Han et al. 2014; Huang et al. 2017). The following Figure 5 interprets the PR parameters.

As seen in Figure 5, feed B has a value that is only slightly different $(0.2)$ from the control feed $A$. The value of fish protein before experiment was $14.17 \%$. After experiment with various treatments, the fish protein value were followed $16.13 \%$ (A), $15.44 \%$ (B), $15.36 \%$ (C), $13.99 \%(\mathrm{D})$, and $10.36(\mathrm{E})$. The protein content of the golden snail meat meal is $10 \%$ and the control feed is thought to be able to be used for protein synthesis. efficient body so that the impact on the high amount of protein stored in the body. This is indicated by the high protein retention value. Fish that were substituted with the $P$. canaliculata meat meal with protein content of $20 \%, 30 \%$, and $40 \%$, respectively, had a lower protein efficiency than $10 \%$ feed. The remaining excess protein consumption will be catabolized by amino acids and nitrogen $(\mathrm{N})$ levels are excreted as ammonia into the environment (Randall and Wright 1987; Hargreaves 1998; Merino et al. 2007; Chew and Ip 2014). Moreover, P. canaliculata meal has $86.36 \%$ value for protein digestibility, slightly lower than fish meal $(88.69 \%)$ (Jintasataporn et al. 2004). Therefore, Hertrampf and PiedadPascual (2000) stated decreasing protein digestibility of higher percentage of $P$. canaliculata meal was perhaps because of the $P$. canaliculata meal fibrous protein structure and high ash percentage $(18.33 \%)$.

The ability of fish to consume a given feed will affect the size of the feed conversion value (FCR). The large or least amount of feed left at the time of feeding can also indicate the high and low FCR value. The more feed is left, the higher the FCR value or the less efficient the feed is for growth and survival. Some factors affecting feed conversion are feed quality, feed amount, fish species, fish size, and water quality (Stickney 1979). As stated in preeceded paragraph, increasing percentage of $P$. canaliculata meals gave a large amount of fibrous protein 
structure and ash (Hertrampf and PiedadPascual 2000). In addition, probably increasing $P$. canaliculata meals affected less feed palatability too. Therefore, scarcely the fish eat the whole feed. Meanwhile, increasing the amount of protein does not mean increasing feed efficiency. Excess amount of protein will actually increase the FCR value and result in suboptimal protein retention (Otchoumou et al 2012; Besson 2016; Omasaki et al. 2017; Devic et al. 2018). Diets $C$ and B have low FCR values. Each differs only 0.11 and 0.12 from feed control A. This can be seen in Figure 6.

Meanwhile, Figure 7 shows the SR parameters. The highest SR parameter value was in the treatment of feed D and was followed by feed B, which differed only 4 points. The SR value is directly proportional to water quality and

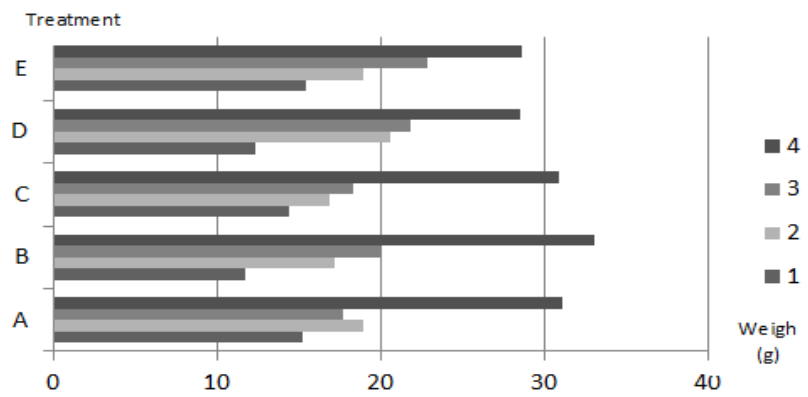

Figure 2. Fish biomass during the study. Note: 1-4: weeks of treatment. A-E: Source of feed protein, i.e. A. $100 \%$ fish meal as a control, B. $90 \%$ fish meal $+10 \%$ P. canaliculata meat meal, C. $80 \%$ fish meal $+20 \%$ P. canaliculata meat meal, D. $70 \%$ fish meal $+30 \%$ P. canaliculata meat meal, E. $60 \%$ fish meal $+40 \%$ $P$. canaliculata meat meal.

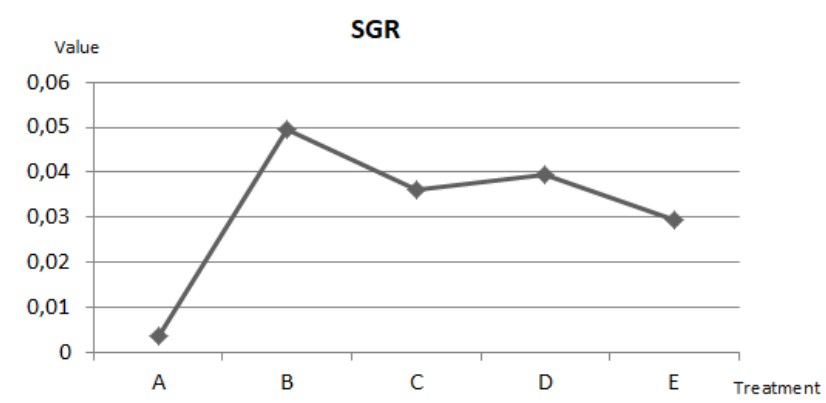

Figure 3. The SGR value of the research

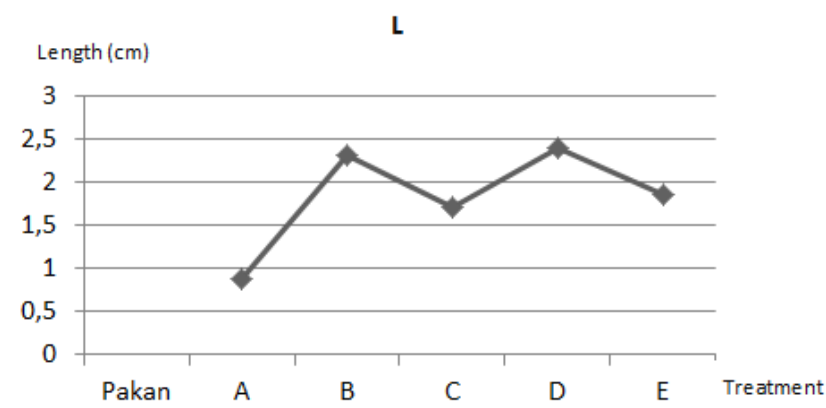

Figure 4. $L$ value of the research feed quality. The size of fish survival is influenced by internal factors which include sex, heredity, age, reproduction, resistance to disease, and external factors including water quality, stocking density, number, and composition of amino acids in the feed (Gatlin 1990). Moreover, water quality is also essential factor in growth and survival of Pasupati catfish. Good temperature and $\mathrm{pH}$ values for freshwater fish farming are $25-30^{\circ} \mathrm{C}$ and $\mathrm{pH} 5.5-$ 8.5 respectively (Ion et al. 2011). Meanwhile, DO values are 4-12 ppm (APHA 2012) and ammonia levels $\left(\mathrm{NH}_{3}\right)$ that do not exceed $0.1 \mathrm{ppm}$ (Hargreaves 2004). This condition is in accordance with Table 1 which shows value of the abiotic parameters for Pasupati catfish during the study. Table 1 data is well-tolerated condition for Pasupati catfish farming.

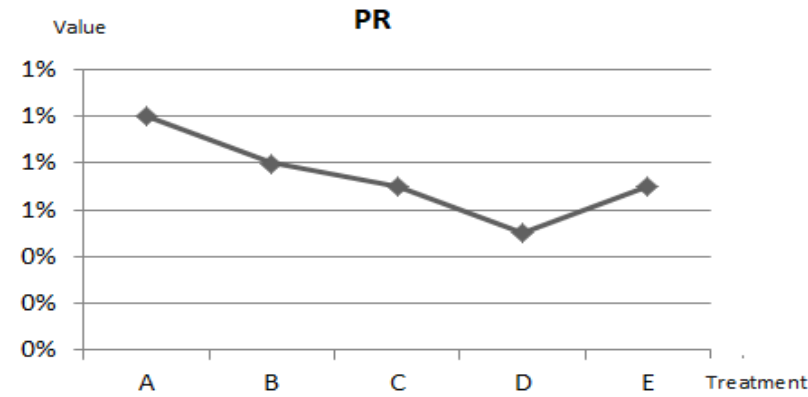

Figure 5. PR value

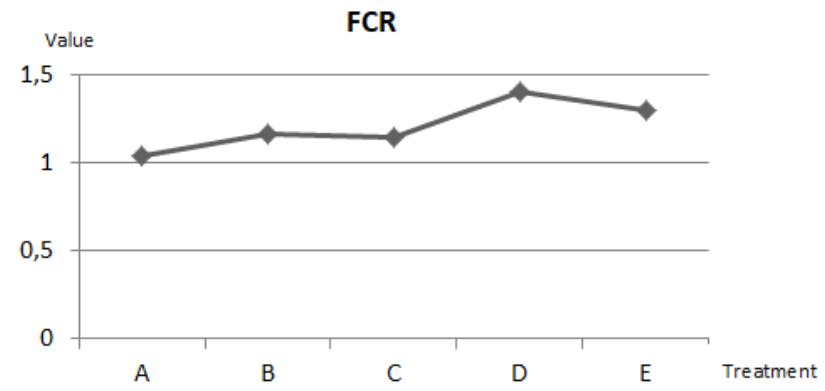

Figure 6. Research FCR Value

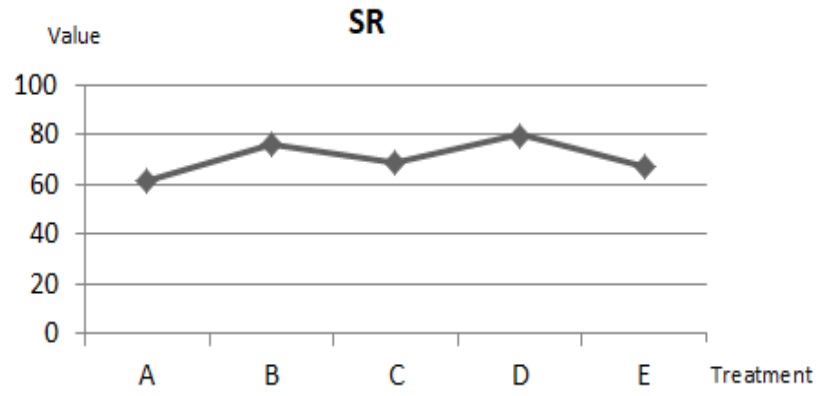

Figure 7. Research SR Value 
Table 1. Value of abiotic parameters during the study

\begin{tabular}{lcccc}
\hline \multirow{2}{*}{ Parameters } & \multicolumn{4}{c}{ Week } \\
\cline { 2 - 5 } & $\mathbf{1}$ & $\mathbf{2}$ & $\mathbf{3}$ & $\mathbf{4}$ \\
\hline $\mathrm{DO}(\mathrm{mg} / \mathrm{dL})$ & 8.42 & 7.3 & 6.34 & 6,23 \\
$\mathrm{~T}\left({ }^{\circ} \mathrm{C}\right)$ & 27.7 & 27.6 & 28.2 & 26.3 \\
$\mathrm{pH}$ & 7.5 & 7.94 & 8.15 & 8.18 \\
$\mathrm{NH}_{3}(\mathrm{mg} / \mathrm{L})$ & 0.19 & 0.09 & 0.15 & 0.08 \\
\hline
\end{tabular}

Calculation of parameters followed by statistical analysis using SPSS 22. After testing SGR variable among treatments by using ANOVA, it yielded no difference between feed treatments A, B, C, D, and E. Then it was continued by using HSD (Honestly Significant Difference) test. The result was insignificant differences between treatments. This analysis is also done for the other variables. ANOVA testing for PR variables among treatments also showed no difference. Insignificant differences also showed among PR treatments after they were analyzed by HSD test. Next is FCR variable which has no difference among treatments after tested by ANOVA. It also resulted in insignificant difference among treatments after HSD tested. For SR variable, ANOVA test gave no difference and HSD test gave insignificant difference among treatments. At last, $\mathrm{L}$ variable also has no difference for ANOVA test and insignificant difference for HSD test among treatments. Based on the calculation of parameter values and statistical analysis, it can be concluded that feed B has high SGR (Figure 2), high PR (Figure 4), and low FCR (Figure 5). This shows that the fish fed with B feed have met their energy needs and essential amino acids, so that the feed protein B is optimal for growth. This statement supports Soengas's point (2014) that appropriate feed treatment is important to optimize growth and a good FCR value.

Calculation of parameters followed by statistical analysis using SPSS 22. The first test was performed by using ANOVA with the results of differences between feed treatments A, B, C, D, and E for the parameter values of SGR, L, PR, FCR, and SR. After that, the analysis was continued with the Honestly Significant Difference test, which later shows insignificant differences between treatments.

Based on previous information, after being given by feed $\mathrm{B}$, fish protein value is increasing from $14,17 \%$ to 15,44\%. Moreover, feed B has high SGR (Figure 2), high PR (Figure 4), and low FCR (Figure 5). This shows that the fish fed with $\mathrm{B}$ feed have met their energy needs and essential amino acids, so that the feed protein B is optimal for growth. This statement supports Soengas's point (2014) that appropriate feed treatment is important to optimize growth and a good FCR value. The addition of feed percentage did not show a better performance for fish growth. Therefore, feed B with a substitution of $10 \%$ golden snail meat meal can be used as an alternative for whole catfish (Pangasius sp.) Without having a negative effect on growth and utilization.

\section{ACKNOWLEDGEMENTS}

The authors would like to thank the Directorate of Higher Education Research and Community Service (DIKTI) for the Research for Novice Lecturer (PDP) grants given in 2020. Thanks also go to the research team for their collaboration.

\section{REFERENCES}

Agustono A, Al Arif MA, Dewi FS. 2016. Pemanfaatan tepung keong mas (Pomacea canaliculata) sebagai substitusi tepung ikan pada pakan udang vannamei (Litopenaeus vannamei) terhadap nilai kecernaan serat kasar dan bahan ekstrak tanpa nitrogen (BETN). J Aquac Fish Health 5 (1): 36-42. DOI: 10.20473/jafh.v5i1.11320

Alfathir S, Estiasih T. 2018. Inovasi pengolahan hama keong mas (Pomacea canaliculata Lamarck) menjadi produk keripik keong mas polita di Cv Polita Nusantara. Jurnal Pangan dan Agroindustri 6 (1): 80-89. [Indonesian]

Anggraini TP, Hudaidah S, Utomo DSC. 2018. Pengaruh proporsi tepung ikan dan tepung keong mas (Pomacea canaliculata) yang berbeda sebagai bahan baku utama pembuatan pakan terhadap pertumbuhan benih udang vannamei (Litopenaeus vannamei). E-Jurnal Rekayasa dan Teknologi Budidaya Perairan 7 (1): 799-806. DOI: 10.23960/jrtbp.v7i1.p799-806. [Indonesian]

APHA."Standard Methods for examination of water and wastewater." 2012. APHA, AWWA, WEF. "Standard Methods for Examination of Water and Wastewater."

Badan Pusat Statistik. 2018. Refleksi Outlook. Refleksi 2018 and Outlook 2019 Kementrian Kelautan dan Perikanan, Jakarta. [Indonesian]

Besson M, Aubin J, Komen H, Poelman M, Quillet E, Vandeputte M, Van Arendonk JAM, De Boer IJM. 2016. Environmental impacts of genetic improvement of growth rate and feed conversion ratio in fish farming under rearing density and nitrogen output limitations. J Clean Prod 116: 100-109. DOI: 10.1016/j.jclepro.2015.12.084

Beveridge MCM, Thilsted SH, Phillips MJ, Metian M, Troell M, Hall SJ. 2013. Meeting the food and nutrition needs of the poor: The role of fish and the opportunities and challenges emerging from the rise of aquaculture. J Fish Biol 83 (4): 1067-1084.

Cárcamo C, Estrada JM, Canales-Cerro C, Hernandez MF, Herrera R, Molina-Burgos BE, Riquelme D, Salas C, Zuniga M, Klarian SA. 2019. Evaluating the relationship between the growth of fish and energy component of their prey. Cogent Environ Sci 5 (1): 1-6.

Chew SF, Ip YK. 2014. Excretory nitrogen metabolism and defense against ammonia toxicity in air-breathing fishes. J Fish Biol 84 (3): 603-638.

Cowie RH. 2002. Apple Snail (Ampullariidae) as Agricultural Pest: Their Biology, Impact and Management. USDA Crop Protection, USA.

Da CT, Hung LT, Berg H, Lindberg JE, Lundh T. 2013. Evaluation of potential feed sources, and technical and economic considerations of small-scale commercial striped catfish (Pangasius hypothalamus) pond farming systems in the Mekong Delta of Vietnam. Aquac Res 44 (3): 427-438.

De Silva SS, Anderson TA.1995. Fish Nutrition in Aquaculture. Chapman and Hall, London.

Devic E, Leschen W, Murray F, Little DC. 2018. Growth performance, feed utilization and body composition of advanced nursing Nile tilapia (Oreochromis niloticus) fed diets containing Black Soldier Fly (Hermetia illucens) larvae meal. Aquac Nutr 24 (1): 416-423.

FAO. 2011. FAO yearbook. Fishery and Aquaculture Statistics 2011/FAO Annuaire. Food and Agriculture Organization of the United Nations, Rome, Italy.

Ganga R, Tibbetts SM, Wall CL, Plouffe DA, Bryenton MD, Peters AR, Runighan CD, Buchanan JT, Lall SP. 2015. Influence of feeding a high plant protein diet on growth and nutrient utilization to combined "all-fish" growth-hormone transgenic diploid and triploid Atlantic salmon (Salmo salar L.). Aquac 446: 272-282. DOI: 10.1016/j.aquaculture.2015.05.010

Gatlin D. 1990. Nutrition of Pond Fishes. Fisheries Research.

Glencross B, Hien TTT, Phuong NT, Cam TuTL. 2011. A factorial approach to defining the energy and protein requirements of Tra 
Catfish, Pangasianodon hypothalamus. Aquac Nutr 17 (2): e396$\mathrm{e} 405$.

Gustiano R, Kristanto AH, Tahapari E, Iswanto B. 2016. Evaluation of Pangasius djambal Bleeker 1846 and Pangasianodon hypophthalmus (Sauvage 1878) hybrids: biometric, growth, and ovarian maturation. Buletin Plasma Nutfah 18 (1): 32-37.

Han T, Li X, Wang J, Hu S, Jiang Y, Zhong X. 2014. Effect of dietary lipid level on growth, feed utilization and body composition of juvenile giant croaker Nibea japonica. Aquaculture 434: 145-150. DOI: 10.1016/j.aquaculture.2014.08.012

Hargreaves JA. 1998. Nitrogen biogeochemistry of aquaculture ponds. Aquaculture 166 (3-4): 181-212. DOI: $10.1016 /$ S0044 8486(98)00298-1

Hargreaves JA, TCS. 2004. Managing Ammonia in Fish Pond. SRAC Publication - Southern Regional Aquaculture Center, USA.

Hayes KA, Joshi RC, Thiengo SC, Cowie RH. 2008. Out of South America: Multiple origins of non-native apple snails in Asia. Divers Distrib 14 (4): 701-712.

Heinitz MC, Figueiredo Silva C, Schulz C, Lemme A. 2018. The effect of varying dietary digestible protein and digestible non-protein energy sources on growth, nutrient utilization efficiencies and body composition of carp (Cyprinus carpio) evaluated with a two-factorial central composite study design. Aquac Nutr 24 (2): 723-740.

Hertrampf JW, Piedad-Pascual F. 2000 Handbook on Ingredients for Aquaculture Feeds. Kluwer Academic Publishers, London.

Hidayat D, Dwi SA, Yulisman. 2013. Kelangsungan hidup, pertumbuhan dan efisiensi pakan ikan gabus (Channa striata) yang diberi pakan berbahan baku tepung keong mas (Pomacea sp). Jurnal Akuakultur Rawa Indonesia 1 (2): 161-172. [Indonesian]

Hu Y, Tan B, Mai K, Ai Q, Zheng S, Cheng K. 2008. Growth and body composition of juvenile white shrimp, Litopenaeus vannamei, fed different ratios of dietary protein to energy. Aquac Nutr 14 (6): 499506.

Huang YS, Wen XB, Li SK, Xuan XZ, Zhu DS. 2017. Effects of protein levels on growth, feed utilization, body composition, amino acid composition and physiology indices of juvenile chu's croaker, Nibea coibor. Aquac Nutr 23 (3): 594-602.

Hung LT, Truc LTT, Huy HPV. 2007. Case study on the use of farmmade feeds and commercially formulated pellets for pangasiid catfish culture in the Mekong Delta, Vietnam. Study and Analysis of Feeds and Fertilizers for Sustainable Aquaculture Development.

Ion S, Cristea V, Bocioc E, Ionescu TI, Coada MT, Enache I. 2011. Monitoring the water quality in the aquaculture recirculating systems. J Environ Prot Ecol 2 (4): 1656-1660.

Jintasataporn O, Tabthipwon P, Yenmark S. 2004. Substitution of golden apple snail meal for fish meal in giant freshwater prawn, Macrobrachium rosenbergii (de Man) diets. Kasetsart J Nat Sci 38: 66-71.

Joshi RC. 2007. Problems with the management of the golden apple snail Pomacea canaliculata: An important exotic pest of rice in Asia. In Vreysen MJB, Robinson AS, Hendrichs J (eds.). Area-Wide Control of Insect Pests. Springer, Dordrecht.

Kaushik SJ, Seiliez I. 2010. Protein and amino acid nutrition and metabolism in fish: Current knowledge and future needs. Aquac Res 41 (3): 322-332.

Marsyha DD, Wijayanti HS, Nuryanto, Anjani G. 2018. Contribution of golden apple snail flour to enhance omega-3 and omega- 6 fatty acids contents in weaning food. IOP Conf Ser: Earth Environ Sci 116: 012075. DOI: $10.1088 / 1755-1315 / 116 / 1 / 012075$

Merino GE, Piedrahita RH, Conklin DE. 2007. Ammonia and urea excretion rates of California halibut (Paralichthys californicus, Ayres) under farm-like conditions. Aquac 271 (1-4): 227-243. DOI: 10.1016/j.aquaculture.2007.06.027
Naylor R. 1996. Invasions in agriculture: Assessing the cost of the golden apple snail in Asia. Ambio 25 (7): 443-448.

Omasaki SK, Janssen K, Besson M, Komen H. 2017. Economic values of growth rate, feed intake, feed conversion ratio, mortality and uniformity for Nile tilapia. Aquac 481: 124-132. DOI: 10.1016/j.aquaculture.2017.04.013

Otchoumou AK, Blé CM, Alla YL, Corraze G, Niamke SL, Diopoh JK. 2014. Effect of crude palm oil incorporation on growth, survival, feed efficiency, and body composition of Heterobranchus longifilis fingerlings. J Appl Aquac 26 (2): 169-178.

Phuong NT, Sinh LX, Thinh NQ. 2007. Economics of aquaculture feeding practices: Vietnam. FAO Fisheries Technical Paper, Rome.

Poernomo N, Utomo NBP, Azwar ZI. 2015. Pertumbuhan dan kualitas daging ikan patin siam yang diberi kadar protein berbeda. Jurnal Akuakultur Indonesia 14 (2): 104-111. [Indonesian]

Pulgar J, Poblete E, Alvarez M, Morales JP, Aranda B, Aldana M, Pulgar VM. 2013. Can upwelling signals be detected in intertidal fishes of different trophic levels?. J Fish Biol 83 (5): 1407-1415.

Randall DJ, Wright PA. 1987. Ammonia distribution and excretion in fish. Fish Physiol Biochem 3 (3): 107-120. DOI: 10.1007/BF02180412.

Ross B, Jauncey K. 1982. A Guide to Tilapia Feeds and Feeding. Institute of Aquaculture, University of Stirling, Scotland.

Ross SD, Nielsen JR, Gislason H, Nielsen A, Andersen NG. 2018. Growth and food consumption of whiting Merlangius merlangus. J Fish Biol 93 (2): 334-343

Sánchez-Lozano NB, Martínez-Llorens S, Tomás-Vidal A, Cerdá MJ. 2009. Effect of high-level fish meal replacement by pea and rice concentrate protein on growth, nutrient utilization and fillet quality in gilthead seabream (Sparus aurata, L.). Aquac 298 (1-2): 83-89. DOI: 10.1016/j.aquaculture.2009.09.028

Saputri DD, Pertiwi MP. 2019. Identifikasi Metabolit Sekunder Ekstrak Keong Mas (Pomacea canaliculata L.). Universitas Pakuan, Bogor. . [Indonesian]

Sari DE, Arma R, Asdar Y. 2019. Preferensi Pomacea canaliculata terhadap perangkap atraktan alami pada pertanian padi. Agrominansia 3 (2): 101-108. [Indonesian]

Savitri A, Hasani Q, Tarsim T. 2015. Pertumbuhan ikan patin siam (Pangasianodon hypopthalmus) yang dipelihara dengan sistem bioflok pada feeding rate yang berbeda. E-Jurnal Rekayasa dan Teknologi Budidaya Perairan 4 (1): 453-460. [Indonesian]

Seo JY, Lee SM. 2008. Effects of dietary macronutrient level and feeding frequency on growth and body composition of juvenile rockfish (Sebastes schlegeli). Aquac Intl 16: 551-560.

Siregar AZ, Lubis KS. 2017. Utilization of golden snail as alternative Liquid Organic Fertilizer (LOF) on paddy Farmers in Dairi, Indonesia. Intl J Sci Technol Res 6 (11): 17-21.

Soengas JL. 2014. Contribution of glucose- and fatty acid sensing systems to the regulation of food intake in fish: A review. Gen Comp Endocrinol 205: 36-48. DOI: 10.1016/j.ygcen.2014.01.015

Stickney RR. 1979. Principles of Warm Water Aquaculture. John Wiley and Sons, Toronto.

Subhan A, Yuwanta T. 2015. The use of Pomacea canaliculata snails in feed to improve quality of Alabio Duck (Anas platyrhynchos Borneo) meat. J Indon Trop Agric 40 (4): 238-244.

Tahapari E, Darmawan J. 2018. Kebutuhan protein pakan untuk performa optimal benih ikan patin pasupati (pangasiid). Jurnal Riset Akuakultur 13 (1): 47-56. [Indonesian]

Zhang NN, Ma QQ, Fan WJ, Xing Q, Zhao YL, Chen LQ, Ye JY, Zhang ML, Du ZY. 2017. Effects of the dietary protein to energy ratio on growth, feed utilization and body composition in Macrobrachium nipponense. Aquac Nutr 23 (2): 313-321. 